\title{
Efektifitas Pelatihan Deteksi Dini Tumbuh Kembang Balita terhadap Keterampilan Ibu dalam Menstimulasi Tumbuh Kembang Balita
}

\author{
Indra Rahmad $^{1(\mathrm{CA})}$, Abdul Haris², Ana Triana Wulandari ${ }^{3}$ \\ 1(CA)Jurusan Keperawatan, Poltekkes Kemenkes Mataram, Indonesia; indrarahmad912@gmail.com \\ (Corresponding Author) \\ ${ }^{2,3}$ Jurusan Keperawatan, Poltekkes Kemenkes Mataram, Indonesia
}

\begin{abstract}
Early childhood is a golden age of child development, a window of opportunity and a critical period. This period is a sensitive period, a period of rapid and important growth and development. At this time children experience very rapid growth and development, both physical growth and motor development, language development and personal social development. This research is a promotive and preventive effort to prevent the occurrence of deviations in the growth of toddlers. The research method used was quasi experiment with pre test and post test control group design with Wilcoxon test and Man Whitney test. Based on the results of the study, it was found that the mother's skills increased after being given skills training in stimulating toddlers in the intervention group with an average pre-test score of 67.61 and an average post-test score of 85.39. Then in the control group there was also an increase in skills with an average pre-test score of 66.94 and post-test average value of 83.52. The results of the analysis showed that the intervention group obtained a $\mathrm{P}$ value of 0.0001 that there was a difference in skills before and after receiving training at the Mpunda Health Center. Meanwhile, in the control group, a $\mathrm{P}$ value of 0.002 was obtained, indicating that there was a difference in skills before and after receiving training at the Mpunda Health Center. For the effectiveness of training on early detection of under-five growth and development on mother's skills in stimulating growth and development of toddlers using the MannWhitney test, the $p$ value of 0.0001 was obtained. These results indicate that training can improve the skills of mothers in providing stimulus to toddlers so that mothers can detect early if there are deviations in the growth and development of toddlers.
\end{abstract}

Keywords: growth and development; Toddler; mother skills

\begin{abstract}
ABSTRAK
Pada masa anak usia dini merupakan masa keemasan perkembangan anak, jendela kesempatan dan masa kritis. Masa ini merupakan masa peka (sensitif), masa pertumbuhan dan perkembangan yang cepat dan penting. Pada masa ini anak mengalami pertumbuhan dan perkembangan yang sangat pesat, baik pertumbuhan secara fisik maupun perkembangan motorik, perkembangan bahasa dan perkembangan personal sosial. Penelitian ini sebagai upaya promotif dan preventif pencegahan terjadinya penyimpangan pertumbuhan balita. Metode penelitian yang digunakan quasy experiment dengan rancangan pre test and post test control group design dengan uji yang digunakan Uji Wilcoxon dan Uji Man Whitney. Berdasarkan hasil penelitian didapatkan keterampilan ibu meningkat setelah diberikan pelatihan keterampilan dalam menstimulas balita pada kelompok intervensi dengan skor rata-rata pre-test 67.61 dan post-test skor rata-rata 85.39. Kemudian pada kelompok kontrol juga terdapat peningkatan keterampilan dengan nilai rata-rata pre-test 66.94 dan post-test nilai rata-rata 83.52. Hasil analisis menunjukkan pada kelompok intervensi didapatkan nilai $\mathrm{P}$ value sebesar 0.0001 bahwa ada perbedaan keterampilan sebelum dan sesudah mendapatkan pelatihan di Puskesmas Mpunda. Sedangkan pada kelompok kontrol didapatkan nilai $\mathrm{P}$ value sebesar 0.002 bahwa ada perbedaan keterampilan sebelum dan sesudah mendapatkan pelatihan di Puskesmas Mpunda. Untuk efektivitas pelatihan deteksi dini tumbuh kembang balita terhadap keterampilan ibu dalam menstimulasi tumbuh kembang balita dengan menggunakan uji Mann-Whitney didapatkan hasil $p$ value 0,0001. Dari hasil tersebut menunjukkan bahwa dengan pelatihan
\end{abstract}


dapat meningkatan keterampilan ibu dalam memberikan stimulus pada balita sehingga para ibu dapat mendeteksi sejak dini jika terjadinya penyimpangan pada tumbuh kembang balita.

Kata kunci: tumbuh kembang; Balita; keterampilan ibu

\section{PENDAHULUAN}

Masa anak usia dini merupakan masa keemasan perkembangan anak, jendela kesempatan dan masa kritis. Masa ini merupakan masa sensitif, masa pertumbuhan dan perkembangan yang cepat dan penting. Apabila terdapat penyimpangan dalam tumbuh kembang dan tidak terdeteksi dini maka akan mempengaruhi tumbuh kembang selanjutnya (Siswanto, 2010).

Pada masa dini anak mengalami tumbuh kembang yang sangat pesat, baik tumbuh secara fisik maupun perkembangan motorik, bahasa dan personal sosial. Masa dua tahun pertama kehidupan anak disebut masa kritis, pada masa ini anak membutuhkan pemenuhan kebutuhan dasar, salah satunya yaitu pemberian stimulasi. Tiga puluh persen kasus penyimpangan tumbuh kembang pada balita disebabkan kurangnya pemberian stimulasi atau rangsangan. Dalam memberikan stimulasi tumbuh kembang diperlukan peran orang tua yang merupakan orang terdekat dengan anak yang dapat memberikan stimulasi secara berkesinambungan.

Pelayanan kesehatan balita meliputi pelayanan pada anak balita sakit dan sehat. Pelayanan kesehatan balita sehat merupakan Pelayanan pemantauan pertumbuhan dan perkembangan dengan menggunakan buku KIA dan skrining tumbuh kembang yang meliputi: Pelayanan kesehatan Balita usia 0 -11 bulan, Pelayanan kesehatan Balita usia 12-23 bulan, dan pelayanan kesehatan Balita usia 24-59 bulan. Untuk pelayanan kesehatan balita sakit yaitu Pelayanan balita dengan menggunakan pendekatan manajemen terpadu balita sakit (MTBS). Pada tahun tahun 2018 cakupan balita yang mendapat pelayanan kesehatan di Provinsi NTB sebesar 96,01\%, nilai tersebut menurun jika dibandingkan dengan capaian tahun 2017 yaitu sebesar 93,02\%.

Berdasarkan data profil kesehatan Provinsi Nusa Tenggara Barat memperlihatkan bahwa jumlah anak balita di Provinsi NTB pada tahun 2018 dengan anak balita usia (6-59 bulan) sebanyak 503.056, anak balita usia (12-59 bulan) sebanyak 391.087, bayi usia (6-11 bulan) sebanyak 111.969. Pada tahun 2017 bima cakupan balita mendapat pelayanan kesehatan sebanyak 103,95 kemudian pada tahun 2018 terjadi penurunan dengan cakupan balita sebanyak 78,89. Pada tahun 2019 jumlah balita di Kota Bima sebanyak 10.473 dengan jumlah balita di SDIDTK sebanyak 7641. Jumlah balita di nilai tumbang terbesar pada puskesmas Mpunda yaitu sebesar 2549 dengan jumlah balita di SDIDTK 2169 kemudian disusul puskesmas Paruga dengan jumlah balita dinilai tumbang sebanyak 2098 dengan jumlah balita di SDIDTK sebanyak 1731. Hal ini dikarenakan luas wilayah dan kepadatan penduduk. (Profil Kesehatan Provinsi Nusa Tenggara Barat Tahun 2018, 2019 dan Dinas Kesehatan Kota Bima, 2019)

Upaya pemantauan secara dini adanya penyimpangan tumbuh kembang pada balita dapat dilakukan oleh orangtua karena merupakan sumber informasi untuk menjadi hasil penilaian dari orangtua dan menjadi prediktor keterlambatan perkembangan pada anak. Oleh karena itu peningkatan pengetahuan, pemahaman, dan kesadaran orangtua perlu upaya-upaya penyebaran informasi pada masyarakat tentang pentingnya pemantauan perkembangan pada anak khususnya balita (Rosada, 2007). Hal ini sejalan 
dengan penelitian yang dilakukan oleh Ina tahun 2017, dengan hasil penelitian menunjukkan terdapat pengaruh antara pendidikan kesehatan tentang deteksi dini perkembangan anak usia balita terhadap peningkatan pengetahuan dan keterampilan ibu dalam melakukan deteksi dini perkembangan anak. Berdasarkan latar belakang tersebut, maka rumusan masalah dalam penelitian ini ingin melihat "Efektifitas Pelatihan Deteksi Dini Tumbuh Kembang Balita Terhadap Keterampilan Ibu Dalam Menstimulasi Tumbuh Kembang Balita Kota Bima”

\section{METODE}

Metode penelitian yang digunakan dalam penelitian ini yaitu quasy experiment dengan rancangan pre test and post test with control group design. Rancangan ini untuk melihat hubungan sebab akibat dengan cara melibatkan kelompok kontrol di samping kelompok eksperimen. (Nursalam, 2013). Populasi dalam penelitian ini yaitu ibu yang memiliki balita 12 bulan - 35 bulan di Puskesmas Mpunda Kota Bima. Penelitian ini menggunakan non probability sampling dengan teknik pengambilan sampel dengan purposive sampling. Dengan sampel penelitian 33 responden intervensi dan 33 responden kontrol, maka jumlah responden adalah 66 orang.

Pada penelitian ini menggunakan KPSP menurut umur. Formulir ini berisi 9-10 pertanyaan tentang kemampuan perkembangan yang telah dicapai anak sesuai dengan usia anak. Alat bantu yang digunakan yaitu kertas, pensil, bola sebesar bola tenis, kubus sebanyak 6 buah kerincingan, kacang tanah, potongan biskuit kecil berukuran $1 \mathrm{~cm}$. Pengumpulan data dilakukan dengan menggunakan pengisian lembar kuesioner dan observasi sebelum dan sesudah penerapan pelatihan pada kelompok kontrol kemudian pada kelompok perlakuan diberikan booklet.

\section{HASIL}

Tabel 1. Karakteristik responden

\begin{tabular}{lcccc}
\hline \multirow{2}{*}{ Karakteristik Responden } & \multicolumn{2}{c}{ Kelompok Intervensi } & \multicolumn{2}{c}{ Kelompok Kontrol } \\
\cline { 2 - 5 } & $\mathrm{n}=33$ & $\%$ & $\mathrm{n}=33$ & $\%$ \\
\hline Usia (mean \pm SD) Min-Max & $(31.52 \pm 4.816)$ & $22-40$ & $(30.12 \pm 4.942)$ & $20-39$ \\
$20-25$ tahun & 2 & 6.1 & 6 & 18.2 \\
26 - 30 tahun & 14 & 42.4 & 12 & 36.4 \\
31 - 35 tahun & 9 & 27.3 & 10 & 30.3 \\
$36-40$ tahun & 8 & 24.2 & 5 & 15.2 \\
Tingkat pendidikan & & & & \\
SMP & 5 & 15 & 6 & 18.2 \\
SMA & 11 & 33.3 & 12 & 36.4 \\
PT & 17 & 51.5 & 15 & 45.5 \\
Usia Balita & & & & \\
$12-14$ bulan & 6 & 18.2 & 6 & 18.2 \\
$15-17$ bulan & 6 & 18.2 & 5 & 15.2 \\
$18-20$ bulan & 5 & 15.2 & 6 & 18.2 \\
21 - 23 bulan & 6 & 18.2 & 4 & 12.1 \\
24 - 29 bulan & 4 & 12.1 & 7 & 21.2 \\
30 - 35 bulan & 6 & 18.2 & 5 & 15.2 \\
\hline
\end{tabular}




\begin{tabular}{ccccc}
\hline \multirow{2}{*}{ Karakteristik Responden } & \multicolumn{2}{c}{ Kelompok Intervensi } & \multicolumn{2}{c}{ Kelompok Kontrol } \\
\cline { 2 - 5 } & $\mathrm{n}=33$ & $\%$ & $\mathrm{n}=33$ & $\%$ \\
\hline Jumlah anak & & & & 39.4 \\
1 orang & 14 & 42.4 & 13 & 39.4 \\
2 orang & 15 & 45.5 & 13 & 21.2 \\
3 orang & 4 & 12.1 & 7 & \\
\hline
\end{tabular}

Berdasarkan tabel 1 dapat diketahui karakteristik responden menurut usia, ditemukan hampir setengahnya usia responden kelompok intervensi 26-30 tahun, berdasarkan tingkat pendidikan responden pada kelompok intervensi maupun kelompok kontrol paling banyak berpendidikan tamatan Perguruan Tinggi. Rentang usia balita pada kelompok intervensi paling sedikit pada rentang 24-29 bulan, sedangkan pada kelompok kontrol terbanyak pada rentang usia balita 24-29 bulan, berdasarkan jumlah anak responden pada kelompok intervensi hampir setengahnya memiliki 2 anak, kemudian pada kelompok kontrol paling banyak memiliki 1 dan 2 anak.

Tabel 2. Distribusi Keterampilan Sebelum Dan Sesudah Diberikan Perlakuan Pada Kelompok Intervensi Dan Kelompok Kontrol Di Puskesmas Mpunda Kota Bima Tahun 2021

\begin{tabular}{lcccc}
\hline \multirow{2}{*}{ Keterampilan } & \multicolumn{2}{c}{ Kelompok Intervensi } & \multicolumn{2}{c}{ Kelompok kontrol } \\
& Pre-test & Post-test & Pre-test & Post-test \\
\hline \multirow{2}{*}{ Baik } & 1 & 30 & 0 & 14 \\
& $3.0 \%$ & $90.9 \%$ & $0 \%$ & $42.4 \%$ \\
Cukup & 29 & 3 & 27 & 18 \\
& $87.9 \%$ & $9.1 \%$ & $81.8 \%$ & $54.5 \%$ \\
Kurang & 3 & 0 & 6 & 1 \\
Mean \pm SD & $9.1 \%$ & $0 \%$ & $18.2 \%$ & $3.0 \%$ \\
Wilcoxon & $(67.61 \pm 5.006)$ & $(85.39 \pm 6.476)$ & $(66.94 \pm 5.711)$ & $(72.27 \pm 6.281)$ \\
\end{tabular}

Berdasarkan tabel 2. menunjukkan pada kelompok perlakuan sebelum diberikan perlakuan keterampilan ibu cukup sebanyak 29 (87.9\%) dan keterampilan kurang sebanyak $3(9.1 \%)$ kemudian pada kelompok kontrol sebelum diberikan perlakuan keterampilan ibu cukup sebanyak $27(81.8 \%)$ dan keterampilan cukup 6 (18.2\%). Dari hasil analisis pada kedua kelompok tersebut didapatkan nilai $P$ value sebesar $0.0001<0.05$ yang berarti $\mathrm{H}_{1}$ diterima bahwa ada perbedaan keterampilan sebelum dan sesudah mendapatkan pelatihan. Sedangkan pada kelompok kontrol didapatkan nilai $P$ value sebesar $0.002<0.05$ yang artinya ada perbedaan keterampilan sebelum dan sesudah mendapatkan pelatihan di Puskesmas Mpunda. Dari hasil tersebut menunjukkan bahwa $0.0001<0.002$ yang artinya ada perbedaan lebih yang signifikan keterampilan ibu sebelum dan sesudah diberikan pelatihan dari pada kelompok kontrol yang diberikan edukasi dengan media booklet.

Tabel 3. Analisis Efektifitas Pelatihan Deteksi Dini Tumbuh Kembang Balita Terhadap Keterampilan Ibu Dalam Menstimulasi Tumbuh Kembang Balita Di Puskesmas Mpunda Kota Bima Tahun 2021

\begin{tabular}{ccccccc}
\hline Variabel & Jenis Kelompok & Mean & SD & p value uji beda & $\begin{array}{c}\text { p value uji } \\
\text { efektifitas }\end{array}$ \\
\hline \multirow{2}{*}{ Keterampilan } & Intervensi & 85.39 & 6.476 & 0.0001 & 0.0001 & -5.791 \\
\hline
\end{tabular}


Berdasarkan tabel 3 pada hasil uji efektivitas dengan hasil $p$ value 0,0001 yang artinya pemberian pelatihan deteksi dini tumbuh kembang balita efektif terhadap peningkatan keterampilan ibu dalam menstimulasi tumbuh kembang balita. Pada tabel didapat nilai $\mathrm{Z}$ hitung adalah -5.791 , sedangkan nilai $\mathrm{Z}$ tabel diperoleh dari tabel $\mathrm{Z}$ dengan alpha $5 \%$ atau 0.05 nilainya sekitar -1.645 . Karena $\mathrm{Z}$ hitung $>\mathrm{Z}$ tabel yaitu $-5.791>-1.645$ atau nilai $p$ value $0.0001<0.05$ yang berarti pelatihan deteksi dini tumbuh kembang efektif dalam meningkatkan keterampilan ibu.

\section{PEMBAHASAN}

Berdasarkan hasil penelitian dapat diketahui bahwa karakteristik responden menurut usia ditemukan hampir setengahnya usia responden kelompok intervensi 26-30 tahun yaitu sebanyak 14 orang (42.4\%). Kemudian pada kelompok kontrol hampir setengahnya berusia responden 26-30 tahun yaitu sebanyak 12 orang (36.4\%). Dalam penelitian ini usia ibu termasuk dalam reproduksi matang dan sehat. Ibu yang berumur 20-35 tahun disebut sebagai "masa dewasa", pada masa ini usia tersebut sudah bisa menjadi problem solving yang dihadapi dengan tenang baik secara emosional, terutama menghadapi fasefase kehamilan, persalinan, nifas dan merawat bayinya hingga memperhatikan tumbuh kembang anak.

Menurut Astuti (2000) Faktor yang mempengaruhi kematangan emosi seseorang salah satunya adalah usia dimana perkembangan kematangan emosi yang dimiliki seseorang sejalan dengan tingkat pertumbuhan dan kematangan fisiologis seseorang Umur mempengaruhi bagaimana ibu menyusui mengambil keputusan dalarn pemberian stimulasi tumbuh kembang pada balita, semakin bertambah umur maka pengalaman dan pengetahuan semakin bertambah. pada kenyataannya umur ibu menentukan derajat kesehatan maternal dan berkaitan dengan kondisi kehamilan, persalinan dan nifas serta cara mengasuh bayinya.

Dengan bertambahnya usia ibu maka pengetahuan ibu juga akan bertambah begitupun sebaliknya. Pengetahuan ibu merupakan domain kognitif dalam pembentukan kemampuan ibu dalam melakukan deteksi dini tumbuh kembang anak. tingkat kematangan dan kekuatan seseorang akan lebih matang dalam berpikir dan bekerja sejalan dengan bertambahnya usia. Hal ini sebagian dari pengalaman dan kematangan jiwa. Hal tersebut juga tampak dalam penelitian ini dimana responden pada kelompok intervensi sebagian besar Perguruan Tinggi yaitu sebanyak 17 orang (51.5\%) kemudian pada kelompok kontrol setengahnya perguruan tinggi yaitu sebanyak 15 orang $(45.5 \%)$.

Rentang usia balita pada kelompok intervensi sebagian kecil 12-14 bulan yaitu sebanyak 6 balita (18.2\%), 15-17 bulan yaitu sebanyak 6 balita (18.2\%), 21-23 bulan yaitu sebanyak 6 balita (18.2\%), 3035 bulan yaitu sebanyak 6 balita (18.2\%) kemudian pada kelompok kontrol rentang usia balita 24-29 bulan yaitu sebanyak 7 balita (21.2\%). Rentang usia tersebut merupakan masa sensitif. Apabila terjadi penyimpangan pada tumbuh kembang dan tidak terdeteksi secara dini maka akan berpengaruh terhadap tumbuh kembang selanjutnya (Siswanto, 2010). Pada masa ini anak mengalami pertumbuhan dan perkembangan yang sangat pesat, baik pertumbuhan secara fisik maupun perkembangan motorik, perkembangan bahasa dan perkembangan personal sosial. Masa dua tahun pertama kehidupan anak disebut masa kritis, pada masa tersebut anak memerlukan pemenuhan kebutuhan dasar yang salah satunya adalah pemberian stimulasi. Sebanyak 30\% kasus penyimpangan tumbuh kembang yang terjadi pada 
balita disebabkan kurangnya pemberian stimulasi. Penelitian sebelumnya yang dilakukan oleh Ina, 2017 dalam Jurnal Info Kesehatan mengatakan bahwa masa anak usia dini merupakan masa keemasan (the golden period), jendela kesempatan dan masa kritis. Serta perkembangan anak.

Jumlah anak responden pada kelompok intervensi hampir setengahnya memiliki 2 anak yaitu sebanyak 15 orang (45.5\%) dan hampir setengahnya memiliki 1 anak yaitu sebanyak 14 orang $(42.4 \%)$ kemudian pada kelompok kontrol hampir setengahnya memiliki 2 anak yaitu sebanyak 13 orang (39.4\%) dan hampir setengahnya memiliki 1 anak yaitu sebanyak 13 orang (39.4\%). Berdasarkan data tersebut rata-rata responden sebelumnya sudah memiliki anak sehingga sudah memiliki pengetahuan dan pengalaman dalam mengurus anak balita.

Dari penelitian yang dilakukan, didapatkan hasil terdapat perbedaan yang bermakna pada keterampilan ibu dengan nilai $p$ value $<0.05$ baik pada kelompok perlakuan maupun kelompok kontrol. Hal ini menunjukkan bahwa pemberian materi deteksi dini tumbuh kembang balita yang diberikan pada ibu sangat bermanfaat untuk meningkatkan keterampilan dalam menstimulasi tumbuh kembang balita yang ditunjukkan dengan adanya peningkatan keterampilan ibu dari sebelum mendapatkan materi hingga setelah mendapatkan materi.

Dalam penelitian ini peneliti menggunakan strategi ceramah, tanya jawab serta demonstrasi kemudian keterampilan ibu dilakukan pengukuran menggunakan formulir KPSP apakah ibu dapat melakukan pengukuran tersebut untuk memantau adanya keterlambatan perkembangan balita maupun proses perkembangan balita yang diberikan pada kelompok intervensi. Kemudian pada kelompok kontrol dilakukan dengan memberikan edukasi tentang pemantauan perkembangan balita dengan menggunakan media booklet. Namun didapatkan data dengan menggunakan metode pelatihan keterampilan ibu pada kategori baik sebanyak 30 (90.9\%) dan keterampilan ibu pada kategori cukup sebanyak $3(9.1 \%)$ sedangkan pada kelompok kontrol didapatkan keterampilan ibu pada kategori baik sebanyak 14 (42.4\%) dan keterampilan ibu pada kategori cukup sebanyak 18 (54.5\%). Dari uraian tersebut dapat dijelaskan bahwa dengan memberikan pelatihan dan pendidikan kesehatan tentang deteksi dini tumbuh kembang balita sangat membantu untuk meningkatkan keterampilan ibu untuk menstimulasi tumbuh kembang balita, namun lebih signifikan dengan memberikan pelatihan. Adapun teori yang mendukung yaitu Reber tahun 1998 (Syah 2003) keterampilan merupakan kemampuan untuk melakukan pola tingkah laku sesuai dengan keadaan untuk mencapai hasil yang sesuai. Komponen Keterampilan yaitu motorik dan penerapan fungsi mental kognitif.

Teori green (1980, dalam Green dan Kreuteur, 1991) menyatakan perilaku sehat seseorang dipengaruhi oleh faktor predisposisi, faktor predisposisinya yaitu keterampilan ibu untuk menstimulasi perkembangan pada balita. Keterampilan sebagai faktor predisposisi merupakan komponen yang mendukung untuk membentuk perilaku seseorang, karena keterampilan merupakan hasil dari proses mencari tahu setelah melakukan penginderaan lihat terhadap suatu obyek tertentu.

Berdasarkan hasil analisis menunjukkan pada kelompok intervensi didapatkan nilai $\mathrm{P}$ value sebesar $0.0001<0.05$ yang berarti $\mathrm{H}_{1}$ diterima bahwa ada perbedaan keterampilan sebelum dan sesudah mendapatkan pelatihan di Puskesmas Mpunda. Sedangkan pada kelompok kontrol didapatkan nilai P value sebesar $0.002<0.05$ yang artinya ada perbedaan keterampilan sebelum dan sesudah mendapatkan 
pelatihan di Puskesmas Mpunda. Dari hasil tersebut menunjukkan bahwa $0.0001<0.002$ yang artinya ada perbedaan yang signifikan keterampilan ibu sebelum dan sesudah diberikan pelatihan dari pada kelompok kontrol dengan menggunakan media booklet. Kemudian peneliti menguji pada kedua kelompok tersebut untuk melihat efektivitas pelatihan deteksi dini tumbuh kembang balita terhadap keterampilan ibu dalam menstimulasi tumbuh kembang balita dengan menggunakan uji Mann-Whitney didapatkan hasil $p$ value 0,0001 yang artinya pemberian pelatihan deteksi dini tumbuh kembang balita efektif terhadap peningkatan keterampilan ibu dalam menstimulasi tumbuh kembang balita.

Hal ini sejalan dengan penelitian yang dilakukan Muflihah yang mengungkapkan bahwa mendeteksi dini tumbuh kembang anak lebih efektif pada ibu yang diberikan sesuai dengan usia tahapan tumbuh kembang anak. Sehingga dapat dikatakan metode pelatihan deteksi tumbuh kembang sesuai dengan tahapan tumbuh kembang usia anak dalam meningkatkan keterampilan ibu dalam menstimulasi tumbuh kembang balita lebih efektif. Hal tersebut juga disampaikan oleh ibu balita pada saat dilakukan interview bahwa materi dapat cepat dipahami karena antara lain jumlah peserta yang dibatasi terkait pandemic covid-19 sehingga memberikan kesempatan untuk mempraktikkan apa yang sudah disampaikan, sedikitnya peserta membuat pemateri dapat fokus dan memberi ruang untuk tanya jawab, penataan tempat duduk yang berjarak sehingga ibu dapat fokus dan tidak terganggu dengan perserta lain.

Aktivitas ibu menemani anak ini yang menjadi dasar pemberian pelatihan stimulasi pada ibu. Ibu memiliki waktu dan momen dalam menemani anak, sehingga akan sangat mempengaruhi meningkatnya keterampilan ibu dalam mendeteksi secara dini tumbuh kembang balita sehingga dapat memberikan stimulasi tumbuh kembang pada anaknya. Pelatihan deteksi dini tumbuh kembang balita dapat meningkatkan keterampilan karena bisa menstimulasi tumbuh kembang pada anak melalui bimbingan fasilitator. Hal ini memberikan pengalaman secara langsung sesuai dengan konsep pemberian stimulasi sesuai tahapan perkembangan usia anak, ini sangat penting dilakukan karena pada masa ini adalah masa masa peka (sensitif), masa pertumbuhan dan perkembangan yang cepat dan penting. Dari uraian tersebut dapat dijelaskan lebih lanjut bahwa dengan memberikan pelatihan dan pendidikan kesehatan tentang deteksi dini tumbuh kembang balita sangat membantu untuk meningkatkan keterampilan ibu untuk menstimulasi tumbuh kembang balita.

\section{KESIMPULAN}

Ada efektifitas pelatihan deteksi dini tumbuh kembang balita terhadap keterampilan ibu dalam menstimulasi tumbuh kembang balita. Dari hasil tersebut artinya ada perbedaan yang signifikan keterampilan ibu sebelum dan sesudah diberikan pelatihan dari pada kelompok kontrol dengan menggunakan media booklet. Untuk melihat efektivitas pelatihan deteksi dini tumbuh kembang balita terhadap keterampilan ibu dalam menstimulasi tumbuh kembang balita dengan pemberian pelatihan deteksi dini tumbuh kembang balita efektif terhadap peningkatan keterampilan ibu dalam menstimulasi tumbuh kembang balita. 


\section{DAFTAR PUSTAKA}

Wicaksono, D.W. (2012). Analisis Faktor Domain yang Berhubungan dengan Kualitas Tidur Pada Mahasiswa Fakultas Keperawatan Universitas Airlangga Surabaya.

Atmikasari. (2008). Deteksi dini gangguan perkembangan anak. . http://www.cybertokoh.com/mod.php?mod=publisher\&op=viewarticle\&artid=39 $\underline{87}$, diperoleh 4 Februari, 2009.

Agrina. (2008). Pengaruh karakteristik orangtua dan lingkungan rumah terhadap perkembangan balita di wilayah kerja puskesmas Sidomulyo rawat inap Pekanbaru. Tesis: tidak dipublikasikan.

Ball, J.W., \& Bindler, C. R. (2003). Pediatric nursing caring for childreen. New Jersey: Pearson Education Inc.

Basford, L. (2006). Teori dan praktek keperawatan: Pendekatan integral pada asuhan pasien. Alih bahasa, Agung Waluyo. Editor, Monica Ester. Jakarta: EGC.

Bear, L.M. (2004). Early identification of infants at risk for developmental disabilities. Pediatric Clin N An, 51, 685-701

Dharmawanto. (2005). Peranan gizi pada pertumbuhan dan perkembangan balita. http://www.hellis.org/modules, diperoleh 11 Februari, 2009.

Dina. (2007). $40 \%$ lebih balita Indonesia kurang gizi. http://islamicspace.wordpress.com/2007/02/16/40-lebih-balita-indonesia-kurang- gizi/, diperoleh 11 Februari, 2009

Dewi, N. S. (2007). Pengaruh pendidikan kesehatan terhadap perubahan pengetahuan dan sikap dalam pencegahan HIV/AIDS pada pekerja seks komersial. Tesis: Tidak dipublikasikan

Maryati, I. (2006). Efektifitas pendidikan kesehatan terhadap aktifitas self care, Thesis Program Magister Keperawatan FIK UI. Jakarta : Tidak dipublikasikan Medline plus Health.

Nies, M.A., \& McEwen, M. (2001). Community health nursing: Promoting the health of populations. ( $3^{\text {rd }}$ ed.), USA: W.B. Saunders Company.

Nurani, A. (2002). Hubungan karakteristik ibu, dukungan keluarga dan pendidikan kesehatan denganperilaku pemberian ASI \& MP-ASI pada bayi usia 0-12 bulan di desa waru Jaya Kecamatan Parung Kabupaten Bogor 2002: Tesis: tidak dipublikasikan.

Pender. (2003). Most frequently ask question about the health promotion models and my professional work and career. http://www. Nursing theory.net, diperoleh 11 Februari 2009).

Potter, A.P., \& Perry, G.A. (2006). Buku ajar fundamental keperawatan: konsep, proses, dan praktik. Volume 2. Edisi 4. Jakarta: EGC.

Rosada, N. (2007). Penyimpangan tumbuh kembang anak harus dapat di deteksi sejak dini. http://www.bandung.go.id/index.php?fa=berita.detail\&id=719, diperoleh 4 Februari, 2009.

Redjeki, G.S. (2005). Kemampuan dan kepuasan ibu terhadap pendidikan kesehatan mengenai stimulasi perkembangan anak usia toddler di kelurahan kemirimuka depok. Tesis. Jakarta : FIK-UI (tidak dipublikasikan).

Riyanto. (2002). Analisis faktor yang paling berpengaruh terhadap perilaku sehat. Thesis Program Magister Keperawatan FIK UI. Jakarta : Tidak dipublikasikan

Soetjiningsih. (1998). Tumbuh kembang anak. Jakarta: EGC. 
Saadah, N. (2004). Penelitian perbedaan tumbuh kembang balita usia 3-18 bulan yang menggunakan buku KIA dengan yang tidak menggunakan buku KIA. http://www.jiptunair.co.id, diperoleh 11 Februari 2009).

Sulistiyawati., \& Pere, M. R. M. H. (2016). Pengetahuan berhubungan dengan sikap ibu dalam kemampuan menstimulasi pertumbuhan dan perkembangan anak balita dengan gizi kurang. Jurnal Ners dan Kebidanan Indonesia, 4(2), 63-69.

Supartini, Y. (2004). Buku ajar konsep dasar keperawatan anak. Jakarta: EGC. Sunarwati. (2003). Praktek pengasuhan dalam menyiapkan anak berkualitas. http://anak.i2.co.id/beritabaru/berita.asp?id=169, diperoleh 12 Februari 2009.

Setiawati, S., \& Dermawan, A.C. (2008). Proses pembelajaran dalam pendidikan kesehatan. Jakarta: Trans Info Media.

Setyowati, T.T. (2004). Pengaruh pendidikan kesehatan perawatan ibu nifas (PK- PIN) terhadap kemampuan merawat diri dan kepuasan ibu post partum di RS panti rapih Yogyakarta. Tesis. Jakarta : FIK-UI (tidak dipublikasikan).

Utami, S. (2008). Pengaruh metode pelatihan terhadap kemampuan ibu dalam deteksi dini perkembangan anak usia 0 - 2 tahun (studi di wilayah kerja Puskesmas Tanah Kalikedinding Surabaya). gdllib@litbang.depkes.go.id, diperoleh 11 Februari, 2009.

Wahyuni. (2004). Studi kuantitatif pengetahuan dan sikap orangtua tentang perkembangan sosialisasi pada anak prasekolah di Desa Ajun Lamhasan Kecamatan Peukan Bada Aceh Besar. Banda Aceh: Skripsi: tidak dipublikasikan.

Wong, D.L. (2004). Pedoman klinis keperawatan pediatrik, edisi 4 (ed-4). Jakarta: EGC 